\section{The role of antioxidative enzymes in copper tolerance strategy of Mimosaceace prosopis farcta growing in a copper mine}

\author{
Masoud Mashhadi Akbar Boojar, \\ Mehdi Hosseini Farahi ${ }^{2}$ \\ 1'Department of Biology, University \\ of Tarbiat Moalem, Tehran; \\ ${ }^{2}$ Young Research Club, Yasouj. Branch \\ Islamic Azad University, Yasouj, Iran
}

\section{Abstract}

In this study, we determined the accumulation levels of copper in tissues and the status of antioxidant enzyme activities in Mimosaceace prosopis fracta against Cu-toxicity in a copper mine. We measured the level of chlorophyll and the activities of superoxide dismutase, glutathione peroxidase and catalase by spectrometry, malondialdehyde and dityrosine by HPLC and the levels of $\mathrm{Cu}$ in tissues and soils by atomic absorption spectrometry. Total and available copper were at toxic levels for plants growing in contaminated soil (zone 1). However, there were no visual or conspicuous symptoms of Cu-toxicity in plant species. Excess copper was transferred into $C$. ambrosioides tissues. The Mimosaceace prosopis frac$t a$ accumulated $\mathrm{Cu}$ in roots and then in leaves, in which the leaves' chloroplasts stored $\mathrm{Cu}$ to approximately two times that of vacuoles. In zone 1, the chlorophyll levels increased significantly in leaves of Mimosaceace prosopis frac$t a$ with respect to the same plant growing in uncontaminated soil (zone 2). The studied plants in zone 1 revealed a significant increase in tissue antioxidant enzyme activities in comparison with the same plants in zone 2. The levels of oxidative damage biomarkers of lipids, such as MDA and proteins such as dityrosine, were higher in tissues of Mimosaceace prosopis fracta that were grown in zone 1 as compared to the same plant species in zone 2, though this difference was not significant. The levels of these biomarkers were higher in roots, stems and leaves, respectively, in both zones. There were significant differences between roots and leaves for these parameters.

We concluded that elevation of antioxidative enzyme activities was a tolerance strategy in the studied plants that protected them against copper toxicity.

\section{Introduction}

Copper (Cu), as well as other heavy metals, enter plants mainly through the root system and play essential roles in a number of physiological processes, such as $\mathrm{Co}_{2}$ assimilation and ATP synthesis. It is a micronutrient for plants and a component of various proteins, particularly those involved in both the photosynthetic (plastocyanin) and the respiratory (cytochrome oxidase) electron transport chain. ${ }^{1}$ Soils may contain elevated levels of copper because of enhanced industrial and mining activities in recent decades. The uptake of copper from soil by plants depends on the ability of the plants to transfer the metal across the soilroot interface and the total amount of $\mathrm{Cu}$ present in the soil. ${ }^{2}$

In excess, the absorbed copper plays a cytotoxic role, induces stress and can unfavorably cause injury and symptoms to plants, including growth retardation and leaf chlorosis, ${ }^{3.5}$ in which the role of oxidative stress and reactive oxygen species (ROS) production may be involved. ${ }^{6,7}$ Under Cu-toxicity, excess copper is an efficient generator of ROS in Fenton-type reactions, leading to disturbance of metabolic pathways and macromolecular damage. ${ }^{8}$ ROS such as singlet oxygen, hydrogen peroxide and hydroxyl radical are generally very reactive molecules possessing an unpaired electron, and in normal conditions the balance between the generation and diminution of ROS is controled by the antioxidant defense system. However, when ROS are not adequately removed, an effect termed "oxidative stress" may result. Excess ROS formed within cells, can provoke oxidation and modification of cellular amino acids, proteins, membrane lipids and even DNA, creating oxidative injury that results in a reduction in plant growth and development. ${ }^{9,10}$

Because the toxic intermediates and ROS are short-lived and difficult to measure directly, an alternative approach for oxidative stress monitoring is quantifying their stable end products of oxidative reactions with cellular macromolecules. ${ }^{11}$ Dityrosine, as a stable biomarker of ROS mediated protein oxidation, and malondialdehyde (MDA), a biomarker of lipid peroxidation, are closely correlated with level of oxidative stress. ${ }^{12,13}$ To control the level of ROS and protect the cells, they possess a number of low molecular mass antioxidants (ascorbate, glutathione, phenolic compounds, tocopherols) and enzymes scavenging ROS, regenerating the active form of the antioxidants and eliminating or reducing the damage caused by them. ${ }^{14}$ SOD, the first major enzyme found in all aerobes, catalyses the dispropor-
Correspondence: Masoud Mashhadi Akbar Boojar, Department of Biology, University of Tarbiat Moalem, N. 49. Dr. Mofateh Avenue, Tehran, PO Box 15614, Iran.

E-mail: aboojar@yahoo.com

Key words: copper mine, antioxidative enzyme, malondialdehyde, dityrosine, vacuoles, chlorophyll, plant tolerance.

Acknowledgments: this work was supported in part by a conjoint grant (N. 4.1145) from the research Ministry of Tarbiat Moallem University. The excellent technical assistance of Faranak Goodarzi is gratefully acknowledged.

Received for publication: 16 May 2010

Revision received: 7 July 2010

Accepted for publication: 8 July 2010 .

This work is licensed under a Creative Commons Attribution 3.0 License (by-nc 3.0).

(C) Copyright M.M.A. Boojar, et al., 2011

Licensee PAGEPress, Italy

International Journal of Plant Biology 2011; 2:e1 doi:10.4081/pb.2011.e1

tion of super oxide radical to $\mathrm{H}_{2} \mathrm{O}_{2}$ and dioxygen. The intracellular level of $\mathrm{H}_{2} \mathrm{O}_{2}$ is regulated by a wide range of enzymes, the most important being catalase and peroxidase. ${ }^{15}$ Glutathione peroxidase protects the membrane lipids from oxidative damage and detoxified the organic peroxides; it can also act on organic hydroperoxides. ${ }^{16}$

Plants growing on Cu-contaminated environments may develop a variety of other defense mechanisms against its toxicity. Among plants, Cu-tolerant genotypes are better able to protect them against homeostatic disturbance and cellular damage by evoking the antioxidant enzyme induction as a general response to toxic effects of heavy metals. ${ }^{17}$ The extent of such tolerance and degree of adaptation is a highly variable mechanism in which the efficiency and capacity of detoxification play an important role. ${ }^{18}$ Additionally, a network of sequestration activities and immobilization functions regulate the uptake, distribution and detoxification of excess metal ions in plants. ${ }^{19}$ In the present work, field surveys have been carried out on the plants growing in a copper mine in Kerman state. The aim of this work was to investigate the ability of a wild-type plant to accumulate $\mathrm{Cu}$, growth responses, antioxidative enzyme activities and the levels of oxidative damage products of lipids and proteins to clarify some aspects of the plant's tolerance mechanism under high copper concentration. 


\section{Materials and Methods}

\section{Copper mine area and study site}

This study was carried out at Chahar Gonbad, located in Sirjan province (Longitude: $0^{\circ}, 11^{\prime}, 56^{\prime \prime} \mathrm{E}$, Latitude: $\left.30^{\circ}, 35^{\prime}, 29^{\prime \prime} \mathrm{N}\right)$. The rainfall was around $465 \mathrm{~mm}$ and there were no industries nearby. The maximum temperature was $+34^{\circ} \mathrm{C}$ and the average annual air temperature was $14^{\circ} \mathrm{C}$. Two zones were considered for plant and soil sampling after a geobotanical survey. The locality of zone 1 was in the center of the copper mine and zone 2 was approximately $9.2 \mathrm{~km}$ south of a waterlogged area of the copper mine. The ecological conditions were similar in both areas. The soil of zone 2 had never been subjected to sources of $\mathrm{Cu}$. The copper mine was one of the most well-known copper mines where the main activity was copper extraction. Tailing had been abandoned for 14 years at the time of sampling.

\section{Plant and soil sampling}

The plant species, Mimosaceace prosopis fracta, as one of the most common native wildtype and endemic plant species, grows naturally in the fields studied in the mine and in the vicinity considered for this study. Growth periods were during the same season in both zones. At each site, plant samples were collected at a specific time of a single growing season and according to the actual landform of the copper mine and the distribution of vegetation before the flowering period.

Care was taken to collect plant samples from both zones while they were at the same age of growth. We had three random regions at each zone of study. We collected at least 5-8 plants of our species from each region considered. Fresh tissues, including roots, stems and mature leaves of collected plants, were considered for three replicate analyses.

Plant species were cleaned in abundant deionised fresh water, rinsed with distilled water and personally identified by an expert botanist. Due care was taken to avoid metal contamination in the process of sampling, washing, drying and grinding. Corresponding soil samples were also collected at the location of plant sampling from the rooting zone (max- imum sampling depth approximately $30 \mathrm{~cm}$ ) and transferred to polythene bags. Excess air was squeezed out, the bags sealed, transferred to the laboratory, and stored at $4^{\circ} \mathrm{C}$ for a maximum of $48 \mathrm{~h}$ prior to analysis. These samples were then air-dried and sieved through a $2 \mathrm{~mm}$ plastic screen. There were six replicates for each soil sample.

\section{Soil analysis}

Dried soil samples were digested with $\mathrm{HCl}+$ $\mathrm{HNO}_{3}+\mathrm{HClO}_{4}(3: 1: 1, \mathrm{v} / \mathrm{v}){ }^{20}$ Total $\mathrm{Cu}$ and other metals were determined by atomic absorption spectrophotometer (AAS) (Analyst 100, Perkin Elmer, USA) using an acetylene-air flame. Diethylenetriaminepentaacetic acid (DTPA)extractable $\mathrm{Cu}, \mathrm{Cd}, \mathrm{Co}, \mathrm{Zn}$ and $\mathrm{Pb}$ contents of 10 g soil samples (sample: DTPA, 1:2, w/v) were determined by AAS. ${ }^{21}$ The reagents and standards for AAS were ultra pure. The detection limits for total and extractable metals in soils were (in $\mathrm{mg} / \mathrm{k}^{-1}$ ): 0.06 for $\mathrm{Cd}, 0.15$ for $\mathrm{Co}$, 0.17 for $\mathrm{Pb}, 0.08$ for $\mathrm{Cu}$ and 0.11 for $\mathrm{Zn}$. This step represents the fraction that is water soluble, most easily available to plants and easily leachable into the groundwater. ${ }^{22}$ Soil nitrate (NO3-) was analyzed according to the method of Primo and Carrasco. ${ }^{23}$ The total Kjeldahl nitrogen (TKN) was determined by the method outlined in Bermen and Mulvaey. ${ }^{24}$ A hydrometric method was used to analyze soil particle size. ${ }^{25}$ Cation-exchange capacity was determined by a standard method. ${ }^{26}$

The $\mathrm{pH}$ and electrolytic conductivity (EC) were determined in a water:soil extract 1:1 using a Beckman pH-meter and a conductivity meter (model HI8633, Hanna Instruments Co.), respectively.

\section{Plant biomass and copper content analysis}

The washed plants were separated into roots and shoots, dried in an oven at $60^{\circ} \mathrm{C}$ for $48 \mathrm{~h}$ and biomass (DW) was then measured. For elemental analysis, the dried plant tissues were ashed in a muffle furnace at $550^{\circ} \mathrm{C}$ for $24 \mathrm{~h}$. The ash was digested with a mixture of $\mathrm{HNO}_{3}$ and $\mathrm{HCLO}_{4}[5: 3(\mathrm{v} / \mathrm{v})]$ and heated in an oven. After cooling, the extracts were diluted and made up to $25 \mathrm{~mL}$ with $1 \mathrm{M} \mathrm{HNO}_{3}$. Copper concentration of the extract was determined by AAS.

\section{Chlorophyll determination}

Fresh and mature leaves $(0.5 \mathrm{~g})$ were extracted with $10 \mathrm{~mL} 80 \%$ acetone, as described by Alan. ${ }^{27}$ The absorbance of extract was measured at 663 and $645 \mathrm{~nm}$ in the UV-Vis light spectrophotometer (model UV-9100). The chlorophyll content was calculated using the equation as follows: $\mathrm{C}_{\mathrm{T}}=20.2 \mathrm{~A}_{645}+8.02 \mathrm{~A}_{663}$.

\section{Chloroplast isolation}

Fresh and mature leaves (5 g) were homogenized for $15 \mathrm{sec}$ with a homogenizer in $50 \mathrm{ml}$ ice-cold grinding medium containing: $0.33 \mathrm{M}$ sorbitol, $1 \mathrm{mM}$ EDTA, 0.1\% BSA, $2 \mathrm{mM}$ sodium ascorbate and $50 \mathrm{mM} \mathrm{K} \mathrm{HPO}_{4}, \mathrm{pH}$ 7.5. The homogenate was filtrated through Miracloth and centrifuged for $1 \mathrm{~min}$ at $1,000 \mathrm{~g}$ at $4^{\circ} \mathrm{C}$ to remove whole cells and cell debris. The intact chloroplasts were pelleted through centrifugation at 4,500 g for $30 \mathrm{sec}$ and were gently resuspended in the same buffer without BSA and centrifuged again in the same conditions. This washing procedure was repeated twice and pelleted chloroplasts were isolated. ${ }^{15}$

\section{Vacuole isolation}

Leaves were floated on an enzyme solution containing $1 \mathrm{mM} \mathrm{CaCl}, 500 \mathrm{mM}$ sorbitol, $0.05 \%$ (w/v polyvinylpyrrolidone), $15 \mathrm{mM}$ MES/Tris pH 5.5, 0.2\% (w/v) bovine serum albumin, $1 \%(\mathrm{w} / \mathrm{v})$ cellulose, $0.5 \%(\mathrm{w} / \mathrm{v})$ Macerozym, 0.01\% (w/v) pectolyase, and agitated for $30 \mathrm{~min}$. Vacuoles were released into the recording chamber by hyposmotic shock treatment of protoplasts in $100 \mathrm{mM} \mathrm{KCl}, 5 \mathrm{mM}$ $\mathrm{MgCl}_{2}, 2 \mathrm{mM}$ EGTA, $1 \mathrm{mM}$ dithiotheritol (DTT) and $5 \mathrm{mM}$ Tris/MES, pH 7.5, adjusted to $\pi=300$ m0sm with D-sorbitol. After setting the vacuoles, the hypotonic solution was carefully replaced by standard bath solution. ${ }^{28}$

\section{Measurement of dityrosine}

Fresh tissue material (1.2 g) was homogenized with $5 \mathrm{~mL}$ of ice-cold $50 \mathrm{mM}$ HEPES$\mathrm{KOH}, \mathrm{pH} 7.2$, containing $10 \mathrm{mM}$ EDTA, $2 \mathrm{mM}$ PMSF, $0.1 \mathrm{mM}$ p-chloromercuribenzoic acid, $0.1 \mathrm{mM}$ DL-norleucine and $100 \mathrm{mg}$ polyclar AT. The plan tissue homogenate was centrifuged at $5,000 \mathrm{~g}$ for $60 \mathrm{~min}$ to remove debris. Purification of $0,0^{\prime}$ _dityrosine in the clear tissue homogenized supernatant fluid was

Table 1. Chemical characteristics of soils of the studied zones.*

\begin{tabular}{|c|c|c|c|c|c|c|c|c|c|c|c|c|c|}
\hline \multirow[t]{2}{*}{ Zone } & \multicolumn{5}{|c|}{ Heavy metal content [mg / (Kg dw)] } & & & & & \multirow[t]{2}{*}{$\mathrm{pH}$} & \multirow[t]{3}{*}{$\begin{array}{c}\text { E. } \mathrm{C}^{\#} \\
(\mathrm{mS} / \mathrm{cm})\end{array}$} & $\begin{array}{l}\text { Nitrogen } \\
(g / k g d w)\end{array}$ & \multirow[t]{3}{*}{$\begin{array}{l}\text { Clay } \quad \text { CEC } \\
(\mathrm{g} / \mathrm{kg})(\mathrm{cmol} / \mathrm{kg})\end{array}$} \\
\hline & $\mathrm{Cu}$ & \multicolumn{2}{|c|}{$\mathrm{Zn}$} & \multicolumn{2}{|c|}{ Co } & \multicolumn{2}{|c|}{$\mathrm{Cd}$} & \multicolumn{2}{|c|}{$\mathrm{Pb}$} & & & Total & \\
\hline $\mathrm{T}$ & E & $\mathrm{T}$ & E & $\mathrm{T}$ & E & $\mathrm{T}$ & E & $\mathrm{T}$ & E & & & & \\
\hline $11132 \pm 61.4 \pi$ & $424 \pm 22.6 \pi$ & $40.17 \pm 6.5 \pi$ & $6.27 \pm 0.53 \uparrow$ & $6.53 \pm 1.86$ & $<0.19$ & $4.26 \pm 0.87$ & $<0.23$ & $11.3 \pm 2.15$ & $<0.36$ & $5.48 \pm 0.39$ & $2.61 \pm 0.28$ & $0.34 \pm 0.07 \quad 1.76 \pm 0.18$ & $19.7 \pm 4.2 \quad 283 \pm 36$ \\
\hline $236.18 \pm 4.42$ & $7.30 \pm 0.86$ & $23.12 \pm 4.6$ & $4.36 \pm 0.41$ & $2.83 \pm 1.15$ & $<0.14$ & $1.53 \pm 0.46$ & $<0.15$ & $7.8 \pm 1.98$ & $<0.36$ & $6.53 \pm 0.26$ & $1.84 \pm 0.16$ & $0.40 \pm 0.08 \quad 2.15 \pm 0.16$ & $14.7 \pm 3.8 \quad 231 \pm 29$ \\
\hline
\end{tabular}


accomplished by preparative HPLC.

$0,0^{\prime}$ dityrosine was recovered by gradient elution from the $\mathrm{C}-18$ column (Econosil C18, $250 \times 10 \mathrm{~mm}$ ). ${ }^{11}$ The composition of eluent varied linearly from acetonitrile-water-TFA (1:99:0.02) to acetonitrile-water-TFA (20:80:0.02) over $25 \mathrm{~min}$. The gradient was started $5 \mathrm{~min}$ after the injection. A flow rate of $4 \mathrm{~mL} / \mathrm{min}$ was used. $0, o^{\prime}$ _dityrosine was analyzed by reversed phase HPLC with simultaneous UV-detection $(280 \mathrm{~nm})$ and fluorescencedetection (ex. $280 \mathrm{~nm}$, em. $410 \mathrm{~nm}$ ). A phenomenex inertsil ODS $2(150 \mathrm{~mm} \times 4.6 \mathrm{~mm}, 5$ $\mu \mathrm{m})$ HPLC column (Bester, Amsterdam, the Netherlands), equipped with a guard column, was used for these analyses. A gradient was formed from $10 \mathrm{mM}$ ammonium acetate, adjusted to $\mathrm{pH} 4.5$ with acetic acid, and methanol, starting with $1 \%$ methanol and increasing to $10 \%$ over $30 \mathrm{~min}$. The flow rate was $0.8 \mathrm{~mL} / \mathrm{min}$. A standard dityrosine sample was prepared according to Amado et al. ${ }^{29}$ Dityrosine was quantified by assuming that its generation from the reaction of tyrosine with horseradish peroxidase in the presence of $\mathrm{H}_{2} \mathrm{O}_{2}$ was quantitative (using the extinction coefficient e315 $=4.5 \mathrm{mM}^{-1} \mathrm{~cm}^{-1}$ at $\mathrm{pH} 7.5$ ).

\section{Malondialdehyde analysis}

Proteins of tissue homogenate were precipitated with $40 \%$ trichloracetic acid (TCA), w/v. The MDA assay was based on the condensation of one molecule malondialdehyde with two molecules of thiobarbituric acid (TBA) in the presence of reduced reagent volumes to increase sensitivity, generating a chromogen with UV absorbance. The TBA + MDA complex was analyzed by HPLC essentially as described by Bird et $a l .{ }^{30}$ Briefly, the HPLC system consisted of a Hewlett Packard 1050 gradient pump (Avondale, PA) equipped with an automatic injector, a 1050 diode-array absorption detector and a personal computer using Chem Station Software from Hewlett Packard. Aliquots of the TBA + MDA samples were injected on a $5 \mathrm{~mm}$ Supelcosil LC-18 reversed phase column $(30 \times 4.6 \mathrm{~mm})$. The mobile phase consisted of $15 \%$ methanol in double-distilled water degassed by filtering through a $0.5 \mu \mathrm{m}$ filter (Millipore, Bedford, MA, USA). The flow rate was $2 \mathrm{~mL} / \mathrm{min}$. MDA + TBA standards were prepared using tetraethoxypropane. The absorption spectra of standards and samples were identical with a characteristic peak at 540 $\mathrm{nm}$. Measurements were expressed in terms of MDA normalized to the sample protein content. Protein content was determined by the Bradford method with standard curves prepared using BSA. ${ }^{31}$

\section{Preparation of enzyme extracts}

Whole tissue (leaves, stems and/or roots) were homogenized $(1: 5 \mathrm{w} / \mathrm{v})$ separately in an ice cold mortar using $50 \mathrm{mM}$ sodium phosphate buffer, $\mathrm{pH} 7.0$, containing $1 \mathrm{M} \mathrm{NaCl}, 1 \%$ polyvinylpyrrolidone and $1 \mathrm{mM}$ EDTA. After centrifugation (20,000 g, $15 \mathrm{~min}$ ), the supernatant (crude extract of leaves) was used to determine enzyme activities, which were measured at $25^{\circ} \mathrm{C}$.

Catalase (EC 1.11.1.6) activity was determined by following the consumption of $\mathrm{H}_{2} \mathrm{O}_{2}$ (extinction co-efficient $0.0394 \mathrm{mM} . \mathrm{cm}^{-1}$ ) at $240 \mathrm{~nm}$ for $30 \mathrm{sec}^{32}$ The assay mixture containing $100 \mathrm{mM}$ potassium phosphate buffer $(\mathrm{pH}$ 7.0), $15 \mathrm{mM} \mathrm{H}_{2} \mathrm{O}_{2}$ and $50 \mu \mathrm{L}$ leaf extract in a 3 ml volume. Unit was defined as $\mu \mathrm{mol} \mathrm{H}_{2} \mathrm{O}_{2}$ decomposed for $1 \mathrm{~min}$. To detect glutathione peroxidase [EC 1.11.1.9 (GSH-Px)] activity, the method of Hopkins and Tudhope with tbutyl hydroperoxide as a substrate was used..$^{33}$ The reaction mixture comprised $50 \mathrm{mM}$ potassium phosphate buffer, pH 7.0, 2 mM EDTA, $0.28 \mathrm{mM}$ NADPH, $0.13 \mathrm{mM}$ GSH, $0.16 \mathrm{U}$ GR, $0.073 \mathrm{mM}$ t-butyl hydroperoxide and enzyme extract (50 mg protein). One unit of GSH-Px activity was defined as the amount of enzyme that catalyzed the oxidation of NADPH [mmol. $\mathrm{min}^{-1} \mathrm{mg}^{-1}$ protein]. SOD activity was determined by the method of Minami and Yoshikawa with $50 \mathrm{mM}$ Tris-Ca-codylic sodium salt buffer, $\mathrm{pH} 8.2$, containing $0.1 \mathrm{mM}$ EDTA. ${ }^{34}$ The reaction mixture was composed of $1.42 \%$ Triton X-100, $0.055 \mathrm{mM}$ nitroblue tetrazolium (NBT), $16 \mathrm{mM}$ pyrogallol and enzyme extract (50 $\mathrm{mg}$ protein). The principle of this reaction is based on the measurement of the concentration of the reduced form of NBT determined at $540 \mathrm{~nm}$. The unit (50\% inhibition) was established according to the definition of McCord and Fridovich. ${ }^{35}$ Unit was defined as the quantity of enzyme required to inhibit the reduction of NBT by $50 \%$ for $1 \mathrm{~min}$.

\section{Statistical analysis}

All statistical analysis was carried out by using procedure available in the SPSS v.10

Table 2. Copper bioconcentration in tissues $(\mathrm{mg} / \mathrm{kg} \mathrm{dw})$ and in organelle $(\mu \mathrm{g} / \mathrm{g} . \mathrm{dw})$ of leaves.*

\begin{tabular}{|c|c|c|c|c|c|c|c|}
\hline Zone & Leaf & $\begin{array}{l}\text { Tissue } \\
\text { Stem }\end{array}$ & Root & Chloroplasts & $\underset{\%^{\#}}{\text { Organelle }}$ & Vacuoles & $\% \#$ \\
\hline 1 & $88.1 \pm 10.3^{\mathrm{b} \pi}$ & $192.5 \pm 18.6^{\text {bq }}$ & $417.6 \pm 31.1$ & $15.85 \pm 1.35^{\text {с⿻ }}$ & 18 & $7.92 \pm 0.81$ & 9 \\
\hline 2 & $12.1 \pm .6$ & $16.2 \pm 2.3$ & $43.6 \pm 5.1$ & $1.82 \pm 0.24$ & 15 & $1.7 \pm 0.19$ & 14 \\
\hline
\end{tabular}

*Data are presented as mean $+\mathrm{SD}$; ${ }^{\mathrm{b}}$ statistically different with respect to roots; ${ }^{\mathrm{C}}$ significant difference as compared with vacuoles; ${ }^{\text {I }}$ statistically different with respect to zone 2 ; "the rate of leaf organelle $\mathrm{Cu}$ to total leaf $\mathrm{Cu}$ (as percent).

Table 3. Chlorophyll content, and biomass of different plant tissues.*

\begin{tabular}{|c|c|c|c|}
\hline \multirow[t]{2}{*}{ Zone } & \multicolumn{2}{|c|}{ Biomass [mg /(g FW)] } & \multirow{2}{*}{$\begin{array}{l}\text { Chlorophyll } \\
\text { [mg /(g FW)] }\end{array}$} \\
\hline & $\begin{array}{c}\text { Shoot } \\
\text { (Stem + leaf) }\end{array}$ & Root & \\
\hline 1 & $73.52 \pm 5.24 \pi$ & $49.11 \pm 3.75$ & $1.06 \pm 0.12$ \\
\hline 2 & $62.15 \pm 4.32$ & $43.22 \pm 3.51$ & $0.71 \pm 0.08$ \\
\hline
\end{tabular}

*Data are presented as mean \pm SD.

Table 4. Antioxidant enzyme activities and biomarkers of lipid peroxidation and protein oxidation in tissues of studied plants.*

\begin{tabular}{|c|c|c|c|c|c|c|}
\hline & Zone & $\begin{array}{c}\text { SOD } \\
\text { (U/mg protein) }\end{array}$ & $\begin{array}{c}\text { GPX } \\
\text { (U/mg protein) }\end{array}$ & $\begin{array}{c}\text { CAT } \\
\text { (uM/min/mg) }\end{array}$ & $\begin{array}{c}\text { MDA } \\
\text { (nmol/mgprotein) }\end{array}$ & $\begin{array}{c}\text { Dityrosine } \\
\text { (nmol/mg protein) }\end{array}$ \\
\hline leaf & $\begin{array}{l}1 \\
2\end{array}$ & $\begin{array}{l}48.35 \pm 4.61^{\# \mathscr{I}} \\
19.34 \pm 3.13\end{array}$ & $\begin{array}{l}8.15 \pm 1.87 \\
2.17 \pm 0.52\end{array}$ & $\begin{array}{l}94.74 \pm 6.51^{\# \mathscr{I}} \\
34.25 \pm 3.62^{\#}\end{array}$ & $\begin{array}{r}10.15 \pm 2.77 \\
7.50 \pm 1.74\end{array}$ & $\begin{array}{l}1.07 \pm 0.26 \\
0.98 \pm 0.19\end{array}$ \\
\hline stem & $\begin{array}{l}1 \\
2\end{array}$ & $\begin{array}{l}31.62 \pm 3.67 \\
10.82 \pm 1.94\end{array}$ & $\begin{array}{l}6.32 \pm 1.14 \\
1.43 \pm 0.38\end{array}$ & $\begin{array}{l}65.63 \pm 5.83^{\# \mathscr{~}} \\
27.53 \pm 2.83\end{array}$ & $\begin{array}{l}16.34 \pm 3.09 \\
12.17 \pm 2.48\end{array}$ & $\begin{array}{l}1.59 \pm 0.28 \\
1.27 \pm 0.24\end{array}$ \\
\hline root & $\begin{array}{l}1 \\
2 \\
\end{array}$ & $\begin{array}{l}25.63 \pm 3.25 \\
14.51 \pm 2.56 \\
\end{array}$ & $\begin{array}{l}5.12 \pm 1.22^{\text {I }} \\
1.15 \pm 0.31\end{array}$ & $\begin{array}{l}50.34 \pm 5.359 \\
22.14 \pm 2.14\end{array}$ & $\begin{array}{l}18.22 \pm 3.28 \\
14.75 \pm 2.86\end{array}$ & $\begin{array}{l}1.95 \pm 0.38 \\
1.54 \pm 0.29 \pi\end{array}$ \\
\hline
\end{tabular}

*Data are presented as mean $+\mathrm{SD}$; ${ }^{\text {" }}$ significant difference as compared with zone 2; ${ }^{*}$ significant difference as compared with roots. 
(SPSS INC., Chicago, IL, USA) statistical package. Each experiment was run on each sample at least in three replicates. Mean \pm SD of test results obtained from all samples collected from all parts for each zone was calculated and the data presented are given as mean \pm SD. Student's t-test was applied to determine the significance of results between different samples. Statistical significance was set at the $\mathrm{P}<0.05$ confidence level.

\section{Results}

Table 1 shows the chemical characteristics of the soil samples that were collected at the locations of plant sampling. There was no statistical difference in $\mathrm{pH}$ of the water extracts of soils, electric conductivity (EC), or cation exchange capacity (CEC) between zone 1 and zone 2. Evaluated $\mathrm{pH}$ and $\mathrm{EC}$ level revealed that the water extracts of the soils in both zones were mildly acidic and there was no problem with salinity; however, the soil samples associated with plants in zone 1 had slightly lower $\mathrm{pH}$ than zone 2 . To better characterize nitrogen species levels, we measured total nitrogen and nitrate levels. Results indicated that both parameters were slightly lower in zone 1 than zone 2, although there was no statistically significant difference. Total contents of each metal ( $\mathrm{Cd}, \mathrm{Co}, \mathrm{Zn}$ and $\mathrm{Pb}$ ) in the soil samples of zone 1 were generally below the maximum allowable concentration of the USA. ${ }^{36}$

The ratio of total $\mathrm{Cu}$ in zone 1 compared to that in zone 2 was approximately 32 fold and approximately 61 fold greater for available $\mathrm{Cu}$; levels that were higher than toxicity threshold levels. ${ }^{38}$ However, the available $\mathrm{Cu}$ concentration for plants in zone 1 was $38 \%$ of total $\mathrm{Cu}$ level. There were no significant differences in the available levels of the studied metals between soils of the two zones except for $\mathrm{Cu}$. The soils of zone 2 displayed no exceptionally high metal concentrations, levels that could not be toxic for plants; particularly cobalt and cadmium were normally low. Table 2 compares the contents of $\mathrm{Cu}$ in roots, leaves and stems of plant species collected from different sites. In general, plant species in zone 1 contained significantly higher $\mathrm{Cu}$ concentrations in studied tissues than those growing in zone 2 soils.

As we compared the levels of $\mathrm{Cu}$ between tissues in Mimosaceace prosopis fracta, we found a significant increase in copper level in roots, stems and leaves, respectively. The roots of Mimosaceace prosopis fracta accumulated $\mathrm{Cu}$ up to approximatley 5 -fold of its level in leaves and to 2-fold its content in stems. The roots of Mimosaceace prosopis fracta grown in zone 1 accumulated most $\mathrm{Cu}$ compared with the tissues of other plant species. On the other hand, the copper levels in shoots (leaves and stems) of Mimosaceace prosopis fracta species was above the critical level for copper toxicity. ${ }^{38}$ The ratio of $\mathrm{Cu}$ in roots of Mimosaceace prosopis fracta growing in zone 1 to that in the roots of the same plants in zone 2 was approximately 9 . With regard to leaves organelle contents of $\mathrm{Cu}$, the plant species in zone 1 had significantly higher $\mathrm{Cu}$ content in their vacuoles and/or chloroplasts with respect to the same plant species in zone 2 . The concentration of copper in vacuoles of Mimosaceace prosopis fracta was 7.92. The level of copper in chloroplasts of $C$. ambrosioides leaves was 2 times higher than vacuole $\mathrm{Cu}$ level.

The biomass characteristics of plant species and the leaves of chlorophyll content are shown in Table 3. In studied plants associated with zone 1, the biomass of shoots (as above ground part of plant) increased significantly with respect to those of zone 2; although there was an insignificant increase in dry weight of its roots. Leaf chlorophyll contents of this plant species collected from zone 1 were also significantly higher than those of zone 2 . Table 4 shows antioxidative enzyme activities and the levels of oxidative damage biomarkers of different parts of the studied plant. The enzyme activities in each of the tissues were significantly higher than those of zone 2 and they were higher in leaves, stems and roots, respectively, in both zones. In addition, the leaves had significantly higher SOD and CAT activities than roots. On the other hand, there was only a significant increase in CAT activity in stems as compared with roots.

Both parameters, MDA and dityrosine, were insignificantly higher in tissues or studied plants that were grown in zone 1 as compared to the same plant species in zone 2. The levels of these biomarkers were higher in roots, stems and leaves, respectively, in both zones. There were significant differences between roots and leaves for these parameters.

\section{Discussion}

In recent decades, enhanced industrial and mining activities have contributed to the increasing occurrence of heavy metals, including copper, in ecosystems. Copper is a widespread contaminant originating from different human activities, including mining and smelting of copper containing ores. Mining activities generate a large amount of waste rock and tailings, which get deposited at the surface. Accordingly, Cu toxicity has important implication for the effects of copper mine ecosystems prone to $\mathrm{Cu}$ stress. In this work, the contaminated field of study was located in a copper mine. Accordingly, the soil analysis revealed normal levels of heavy metals ( $\mathrm{Pb}, \mathrm{Co}$ and $\mathrm{Cd}$ ) and toxic levels of $\mathrm{Cu}$ in which the rate of available concentration of this metal was quite high (approximately 37\%) for plant growth. This high $\mathrm{Cu}$ availability may be attributed to our soil $\mathrm{pH}$ characteristic. It has been confirmed that low levels of this parameter cause an increase in $\mathrm{Cu}$ solubility and its release from the soil phase leading to the increase in copper uptake by roots. ${ }^{39}$ In accordance with our findings, soil analysis reported in the Cyprus Skouriotissa copper mine showed that there was mild acidity and copper content of up to $787 \mathrm{mg}(\mathrm{kg} \mathrm{DW})^{-1} .^{40}$ In our zones of investigation, normal growth of our studied plant in metalliferous soils without any visual and conspicuous symptoms of Cu-toxicity implied that it was tolerant to toxic levels of $\mathrm{Cu}$. The plant species was endemic in copper mines and naturally adapted to contaminated soils by developing tolerance mechanisms to metal stress. Most of these mechanisms have already been recognized, such as accumulation of metals and internal protective responses that vary among plants species and among different tissues. $^{41}$

Based on our results, the studied plant could not be considered hyperaccumulators because the accumulation levels of copper in tissues were lower than $1,000 \mu \mathrm{g} / \mathrm{gr}$, the prescribed threshold limit for hyperaccumulators. ${ }^{42}$ Our finding was in agreement with the reports of Shu et al. ${ }^{43}$ and Brun et al. ${ }^{44}$ who illustrated that metal accumulation ability varies between species and is affected by their intrinsic characteristics. In their study, copper was accumulated differently in Paspalum distichum and Cynodon dactylon, metal tolerant plants, collected from the Lechang tailing copper mine in China. They also found higher copper contents in roots of Cynodon dactylon and in shoots of Paspalum distichum with respect to their other tissues. Such patterns of copper bioaccumulation and partitioning among different parts of tolerant plants have been reported in many other studies. ${ }^{4548}$ Furthermore, Pistacia terebinthus and Cistus creticus collected from the Skouriotissa copper mine accumulated a considerable amount of the absorbed copper in their roots, although Bosea cypria accumulated most copper in its leaves. ${ }^{40}$ In agreement with these documents, our studied plant showed copper accumulation partitioning in which most copper was accumulated or bounded in roots with restricted translocation of copper toward shoots. On the other hand, many studies confirmed that when copper is in excess, it can promote and stimulate the generation of Fenton-type reactive oxygen species leading to an increase in antioxidative enzyme activities as a defense system. ${ }^{18,49,50}$ This response to excess copper can vary among plant species and among different tissues. ${ }^{18}$ Accordingly, the observed increase in each antioxidative enzyme activity in Mimosaceace prosopis fracta from a Cu-contaminated zone could be due 
to the induction of excess $\mathrm{Cu}$. We also conclude that the induction levels on the studied enzyme activities in this plant were sufficient to protect proteins, chlorophyll and lipids of some parts of plants against ROS attack. On this basis, the biomass of each plant part and leaf chlorophyll content of this plant associated with zone 1 were higher than the same plant growing in zone 2, although this difference was not statistically significant. However, there was no significant difference in MDA and dityrosine levels. In comparison, the roots of Mimosaceace prosopis fracta revealed a significant increase in MDA and dityrosine with respect to leaves that may be attribute to considerable low activities of antioxidative enzymes in roots. From our documents, many studies illustrated an inhibition effect of excess copper on antioxidative enzymes. ${ }^{51,52}$ Because of a higher copper content in the roots of this plant, it would exert a toxic effect on antioxidant enzymes leading to a significant decrease in their activities with respect to leaves. On the basis of our findings and illustrated documents, we believe that antioxidative enzymes play a key role in the defense system against oxidative damage and in the tolerance of Mimosaceace prosopis fracta in a $\mathrm{Cu}-$ rich environment.

To conclude, this study showed that antioxidative enzyme responses to $\mathrm{Cu}$-stress protected Mimosaceace prosopis fracta against oxidative damage and were involved in the plant's tolerance in a copper mine.

\section{References}

1. Demirevska-Kepova KL, Simova-Stoilova Z, Stoyanova R, et al. Biochemical changes in barley plants after excessive supply of copper and manganese. Environ Exp Bot 2004;52:253-66.

2. Agata F, Ernest B. Meta-metal interactions in accumulation of $\mathrm{V} 5+, \mathrm{Ni} 2+, \mathrm{Mo6}+$, $\mathrm{Mn} 2+$ and $\mathrm{Cu} 2+$ in under and above ground parts of Sinapis alba. Chemospher 1998;36:1305-17.

3. Waldermar M, Ryszard R, Teresa U. Effect of excess $\mathrm{Cu}$ on the photosynthetic apparatus of runner bean leaves treated at two different growth stages. Physiologia Plantarum 1994;91:715-21.

4. Baker AJM, Proctor J. The influence of cadmium, copper, lead, and zinc on the distribution and evolution of metallophytes in British Island. Plant System Evol 1990;173:91-108.

5. Lewis S, Donkin ME, Depledge MH. Hsp70 expression in Enteromorpha intestinalis (Chlorophyta) exposed to environmental stressors. Aquat Toxicol 2001;51:277-91.

6. Stadtman ER, Oliver CN. Metal-catalyzed oxidation of proteins. J Biol Chem 1991;266:2005-8.

7. Thomas F, Malick C, Endreszl EC, et al. Distinct responses to copper stress in the halophyte, Mesembryan-themum crystallium. Physiologia Plantarum 1998;102:3608.

8. Hegedus A, Erdei S, Horvath G. Comparative studies of $\mathrm{H} 2 \mathrm{O} 2$ detoxifying enzymes in green and greening barley seedlings under cadmium stress. Plant Sci 2001;160:1085-93.

9. Hernandez-Jimenez MJ, Lucas MM, Rosario MF. Antioxidant defence and damage in senescing lupin nodules. Plant Physiol Biochem 2002;40:645-57.

10. Ogawa K, Iwabuchi M. A mechanism for promoting the germination of Zinnia elegans seeds by hydrogen peroxide. Plant Cell Physiol 2001;42:286-91.

11. Orhanl H, Vermeulen NPE, Tump C, et al. Simultaneous determination of tyrosine, phenylalanine and deoxyguanosine oxidation products by liquid chromatographytandem mass spectrometry as non-invasive biomarkers for oxidative damage. J Chromato B 2004;799:245-54.

12. Halliwell B and Gutteridge JMC. Mechanisms of damage to cellular targets by oxidative stress: lipid peroxidation. Chap 4. In: Halliwell B and Gutteridge JMC (eds.). Free radicals in biology and medicine. Oxford Science Publication 1998; 284-306.

13. Feda EA, Kevin JB, Colin JB, et al. 2004. Metal catalyzed oxidation of tyrosine residues by different oxidation systems of copper/hydrogen peroxide. J Inorg Biochem 2004;98:173-84.

14. Alscher RG, Donahue JL, Cramer CL. Reactive oxygen species and antioxidants: Relationships in green cells. Physiol Plant 1997;100:224-33.

15. Rusina Y, Kaloyan N, Christov L, et al. Antioxidative enzymes in barley plants subjected to soil flooding. Environ Exp Bot 2004;51:93-101.

16. Kantol M, Sarranen M, Vanha PT. Selenium and glutathione peroxidase in serum, plasma of men and bulls. J Reprod Fertil 1988;83:785-94.

17. Van-Assche F, Clijsters H. Effect of the metals on enzyme activity in plants. Plant Cell Environ 1990;13:195-206.

18. Lombardi L, Sebastiani L. Copper toxicity in Prunus cerasifera: growth and antioxidant enzymes responses of in vitro grown plants. Plant Sci 2005;168:797-802.

19. Clemens S. Molecular mechanisms of plant metal tolerance and homeostasis. Planta 2001;212:475-86.

20. Yuan DW. Compared study on the pretreatment methods for measuring soil total copper, zinc, lead, cadmium, nickel and manganese. Agro-Environmental Protection Sinica 1988;7:34-6.

21. Page AL, Miler RH, Keeney DR. Methods of soil analysis. Part 2. Chemical and microbiological properties. Second ed. Agronomy N. 9. American Society of Agronomy and soil science society of America, Madison, Wisconsin, 1982.

22. Siebe C. Heavy metal availability to plants and soils irrigated with wastewater from Mexico City. Water Sci Technol 1995;32:2934.

23. Primo YE, Carrasco DJM. Quimica Agricola, 1st. ed. Alhambra SA (ed), Barcelona, Spain, 1973;pp.233-371.

24. Bermen JM, Mulvaney, C.S., 1982. Nitrogen-total. In: Methods of soil analysis, Agronomy Monograph 9, part 2, second ed.

25. Wang RZ. Soil particle density, bulk density and porosity determination; soil particle analyses; soil moisture determination. In: Li, UK (ed.), Routine Methods of Agrochemistry and Soil, Agro-chemistry Committee of Chinese Society of Soil Science. Science Press, Beijing, 1989:1566.

26. Bower CA, Reitemeier RF, Fireman M. Exchangeable cation analysis of saline and alkali soils. Soil Sci 1952;73251-261.

27. Alan RW. The spectral determination of chlorophyll a and b, as well as total carotenoids, using various solvents with spectrophotometers of different resolution. Plant Physiol 1994;144:307-13.

28. Scholz-Starke J, Angeli AD, Ferraretto C, et al. Redox-dependent modulation of the carrot SV channel by cytosolic pH. FEBS letters 2004;576:449-54.

29. Amado R, Aeschbach R, Neukom H. Dityrosine: in vitro production and characterization. Methods Enzymol 1984;107: 377-88.

30. Bird BR, Hung SSO, Hadley M, et al. Determination of malonaldehyde in biological materials by high-pressure liquid chromatography. Anal Biochem 1983;128: 240-4.

31. Bradford MM. A rapid and sensitive method for the quantification of microgram quantities of protein utilizing the principle of protein dye binding. Anal Biochem 1976;72:248-54.

32. Aeby H. Catalase in vitro. Methods Enzymol 1984;105:121-6.

33. Hopkins J, Tudhope GR. Glutathione peroxidase in human red cells in health and disease. Br J Haematol 1973;25:563-75.

34. Minami M. Yoshikawa H. A simplified assay method of superoxide dismutase activity for clinical use. Clin Chim Acta 1979;92:337-42.

35. McCord J, Fridovich I. Superoxide dismutase. An enzymatic function for ery- 
throcuprein (hemocuprein). J Biol Chem 1969;244:6049-55.

36. Kabata-Pendias A. Agricultural problems related to excessive trace metals contents of soil. In: Salmons W, Forsther U (eds) Concerning heavy metals: problems and solutions/salmons. Springer-Verlag, Berlin 1995:19-31.

37. ICRCL. Inter-departmental committee on the redevelopment of contaminated land: Guidance notes (59/83). Guidance on the assessment and redevelopment of contaminated land. Second ed. HMSO, London 1987:19.

38. Robson AD, Reuter DJ. Diagnosis of copper deficiency and toxicity. In: Loneragan JF, Robson AD, Graham RD (eds) Copper in soils and plants. Academic Press, London, 1981:287-312.

39. Watmough SA, Dickinson NM. Dispersal and mobility of heavy metals in relation to three survivals in an aerially-contaminated woodland ecosystem. Environ Pollut 1995;90:139-42.

40. Johansson L, Xydas C, Messios N, et al. Growth and $\mathrm{Cu}$ accumulation by plants grown on $\mathrm{Cu}$ containing mine tailing in Cyprus. Applied Geochemistry 2005;20:

\section{1-7.}

41. Nicolau A, Martins MJ, Mota M, et al. Effect of copper in the protistan community of activated sludge. Chemosphere 2005; 58:605-14.

42. Reeves R, Baker A. Metal accumulating plants. In: Raskin I, Ensley B (eds). Phytoremediation of toxic metals-using plants to clean up the environment. John Wiley and Sons, New York, 2000:193-229.

43. Shu WS, Ye ZH, Lau CY, et al. Lead, Zinc and Copper accumulation and tolerance in populations of Paspalum disticum and Cynodon dactylon. Environ Pollution 2002; 120:445-53.

44. Brun LA. Maillet J, Hinsinger $\mathrm{P}$, et al. Evaluation of copper-contaminated vineyard soils. Environ Pollution 2001;111:293302.

45. Marschner $\mathrm{H}$ (ed). Mineral nutrition of higher plants. 2nd ed, Academic Press, London, 1995.

46. Stoltz E, Greger M. Accumulation properties of $\mathrm{As}, \mathrm{Cd}, \mathrm{Cu}, \mathrm{Pb}$ and $\mathrm{Zn}$ by four wetland plant species growing on submerged mine tailings. Environ Exp Bot 2001;47:271-80.

47. Pyatt FB. Copper and lead bioaccumulation by Acacia retinoides and Eucalyptus torquata in sites contaminated as a consequence of extensive Ancient mining activities in Cyprus. Ecotoxicol Environ Safety 2001;50:60-4.

48. Mulligan CN, Yong RN, Gibbs BF. Remediation technologies for metal-contaminated soils and groundwater: an evaluation. Engineering Geol 2001;60:193-207.

49. Devi SR, Prasad MNV. Copper toxicity in Ceratophyllum demersum L., a free floating macrophyte. Plant Sci 1998;138:15765 .

50. Weckx JEJ, Clijesters HMM. Oxidative damage and defense mechanisms in primary leaves of Phaseolus vulgaris as a result of root assimilation of toxic amount of copper. Physiol Plant 1996;96:506-12.

51. Maribel LD, Satoshi T. Antioxidant responses of rice seedlings to salinity stress. Plant Sci 1998;135:1-9.

52. Luna CM, Gonzales CA, Trippi VS. Oxidative damage caused by an excess of copper in oat leaves. Plant Cell Physiol 1994;33:11-5. 